\title{
Candida phangngensis sp. nov., an anamorphic yeast species in the Yarrowia clade, isolated from water in mangrove forests in Phang-Nga Province, Thailand
}

Correspondence

Savitree Limtong fscistl@ku.ac.th

\author{
Savitree Limtong, ${ }^{1}$ Wichien Youngmanitchai, ${ }^{1}$ Hiroko Kawasaki ${ }^{2,3}$ \\ and Tatsuji Seki ${ }^{2}$ \\ ${ }^{1}$ Department of Microbiology, Faculty of Science, Kasetsart University, 50 Paholyothin Road, \\ Bangkok 10900, Thailand \\ ${ }^{2}$ The International Center for Biotechnology, Osaka University, 2-1 Yamada-oka, Suita-City, \\ Osaka 565-0871, Japan \\ ${ }^{3}$ NITE Biological Resource Center (NBRC), Department of Biotechnology, National Institute of \\ Technology and Evaluation, 2-5-8 Kazusakamatari, Kisarazu-City, Chiba 292-0818, Japan
}

\begin{abstract}
Two yeast strains (TM2-16 and PT1-1 $7^{\top}$ ) were isolated by membrane filtration from samples of estuarine water collected from two mangrove forests, in Khao Lumpee-Haad Thaimueang National Park and Mu Ko Ra-Ko Prathong National Park, Phang-Nga Province, Thailand. Analysis of the D1/D2 domain of the large-subunit rDNA sequences revealed that the sequences of the two strains were identical. The closest species in terms of pairwise sequence similarity was Candida galli, but the level of nucleotide substitutions (13.2\%) was sufficient to justify the description of a separate species. Phylogenetic analysis demonstrated that the two strains occupy a basal position with respect to Yarrowia lipolytica and C. galli of the Yarrowia clade, supported by a high bootstrap value. The two strains showed identical phenotypic characteristics, including proliferation by multilateral budding, absence of ascospores and ballistoconidia and negative Diazonium blue B and urease reactions. The major ubiquinone was Q-9. On the basis of the above findings, these two strains were assigned to a single novel species of the genus Candida, for which the name Candida phangngensis sp. nov. is proposed. The type strain is PT1-17 ${ }^{\top}$ (=BCC $21231^{\top}=$ NBRC $101967^{\top}=$ CBS $10407^{\top}$ ).
\end{abstract}

Yeasts are widely distributed in nature in both terrestrial and aquatic habitats. In aquatic habitats, yeasts are present in both freshwater and seawater (Hagler \& Ahearn, 1987; Lachance \& Starmer, 1998). Mangrove forests, or intertidal forests, are plant communities in saline coastal habitats that are distributed over a wide range of geographical zones (Aksornkoae, 1999). Yeasts are abundant in the water adjacent to and within mangrove swamps (Fell et al., 2004). Fell et al. (2004) reported that the population of yeasts in Mangrove Cay creek, which is on the Little Bahama Bank, ranged from 20 to 29000 cells $1^{-1}$ and described Lachancea meyersii from 18 strains isolated from waters in mangrove habitats in the northern Bahamas.

Abbreviations: LSU, large subunit; SSU, small subunit.

The GenBank/EMBL/DDBJ accession numbers for the sequences of the D1/D2 domain of the LSU rDNA of strains TM2-16 and PT1-17 are $\mathrm{AB} 304771$ and $\mathrm{AB} 304772$.
The Yarrowia clade consists of only a small number of ascomycetous yeast species, including the sexual species Yarrowia lipolytica and the asexual species Aciculoconidium aculeatum, Candida hispaniensis, C. galli, C. incommunis and C. bentonensis (Kurtzman \& Robnett, 1998; Kurtzman, 2005; Péter et al., 2004).

An investigation was carried out of yeasts in water from two mangrove forests in Phang-Nga Province in the southern part of Thailand. The first sampling site was a canal leading to the Andaman Sea in a mangrove forest in Khao Lumpee-Haad Thaimueang National Park $\left(8^{\circ} \mathrm{N} 98^{\circ}\right.$ E), Amphoe Thaimueang. The second sampling site was in the Andaman Sea around Mu Ko Ra-Ko Prathong National Park ( $\left.9^{\circ} \mathrm{N} 98^{\circ} \mathrm{E}\right)$, Amphoe Khura Buri and Amphoe Takuapa. The water samples were from the surface and from below the surface at a depth of approximately 3-5 m with a Niskin Biosampler. Salinity, $\mathrm{pH}$ and temperature of all water samples were determined immediately at the places of collection. A total of 14 samples were collected at 
four points in Khao Lumpee-Haad Thaimueang National Park in January, March and May 2005. Eighteen samples were collected at three points in Mu Ko Ra-Ko Prathong National Park in March and May 2005.

Yeast enumeration and isolation were carried out by membrane filtration of water samples. Colonies on membrane filters were counted and one colony of each macromorphology type from each water sample was purified by cross-streaking on YM agar. The yeast populations in the water samples taken from the mangrove forest in Khao Lumpee-Haad Thaimueang National Park ranged from 90 to 1580 c.f.u. per $100 \mathrm{ml}$ and those in the samples taken around $\mathrm{Mu}$ Ko Ra-Ko Prathong National Park ranged from 66.5 to 175 c.f.u. per $100 \mathrm{ml}$. Salinities of the water samples from the two mangrove forests were only slightly different. The samples from Khao Lumpee-Haad Thaimueang National Park and from $\mathrm{Mu}$ Ko Ra-Ko Prathong National Park exhibited salinities of 28.0-33.0 and 29.7-32.7 p.p.m., respectively. The temperatures of the water samples from the two national parks were 29.2-33.5 and $32-36{ }^{\circ} \mathrm{C}$, respectively, while the pHs were $7.2-7.8$ and 7.8-7.9, respectively.

Yeasts could be isolated from all water samples. Fifty to $200 \mathrm{ml}$ water was filtered through $0.8 \mu \mathrm{m}$ membrane filters, which were placed on acidified yeast extract-malt extract (YM) broth $(0.3 \%$ yeast extract, $0.3 \%$ malt extract, $0.5 \%$ peptone, $1 \%$ glucose; adjusted to $\mathrm{pH} 3.7-3.8$ with $1 \mathrm{M}$ $\mathrm{HCl}$ ) supplemented with $0.025 \%$ sodium propionate and $200 \mathrm{mg}$ chloramphenicol $\mathrm{l}^{-1}$ and incubated for 2-3 days at room temperature. Yeast colonies were picked and purified by cross-streaking on YM agar. On the basis of differences in colony morphology, 26 and 23 yeast strains obtained from the two parks were selected as representatives for identification. Identification on the basis of comparison of sequences of the D1/D2 domain of the large-subunit (LSU) rDNA revealed that, of the 26 strains from the water samples from Khao Lumpee-Haad Thaimueang National Park, 19 strains represented eight described ascomycetous species, namely Candida conglobata, C. membranifaciens, C. parapsilosis, C. picinguabensis, C. tropicalis, Lodderomyces elongisporus, Pichia caribbica and P. guilliermondii, and one described basidiomycetous species, Rhodotorula mucilaginosa. The other seven strains, including TM2-16, were found to represent novel species. Four of these strains have previously been reported as a novel species, Candida thaimueangensis (Limtong et al., 2007b). Identification of 22 strains derived from the water samples in Mu Ko Ra-Ko Prathong National Park resulted in four described ascomycetous species, $C$. parapsilosis, Pichia caribbica, P. fabianii and P. guilliermondii, one undescribed ascomycetous species, Candida cf. glabrata UWO (PS) 98-110.4, one described basidiomycetous species, Rhodotorula mucilaginosa, one yeast-like fungal species, Aureobasidium pullulans, and three novel strains, including PT1-17 ${ }^{\mathrm{T}}$.

In this report, strains TM2-16 and PT1-17 ${ }^{\mathrm{T}}$, which are placed in the Yarrowia clade in the phylogenetic tree based on sequences of the D1/D2 domain of the LSU rDNA, are described as representing a novel species of the genus Candida.

Methods for DNA isolation, amplification of the D1/D2 domain of the LSU and the small-subunit (SSU) rDNA by PCR and sequencing with the ABI BigDye Terminator cycle sequencing kit version 3.1 (Applied Biosystems) using an ABI PRISM 3100 automated DNA sequencer (Applied Biosystems) were described previously (Limtong et al., 2007a). The sequences were compared pairwise by BLAST search (Altschul et al., 1997) and were aligned with sequences of related species retrieved from GenBank using the multiple alignment program CLUSTAL_X version 1.81 (Thompson et al., 1997). A phylogenetic tree was constructed from the evolutionary distance data with Kimura's two-parameter correction (Kimura, 1980) by using the neighbour-joining method (Saitou \& Nei, 1987). Confidence for phylogenetic tree was estimated from bootstrap analysis (1000 replicates) (Felsenstein, 1985).

The strains were characterized morphologically, biochemically and physiologically according to the standard methods described by Yarrow (1998). Assimilation of nitrogen compounds was examined on solid media with starved inocula following the method of Nakase \& Suzuki (1986). Growth at various temperatures was determined by cultivation on yeast extract-peptone-dextrose (YPD) agar ( $1 \%$ yeast extract, $2 \%$ peptone, $2 \%$ glucose and $2 \%$ agar). Ubiquinones were extracted from intact packed cells cultivated in YPD broth on a rotary shaker at $28{ }^{\circ} \mathrm{C}$ for 24-48 $\mathrm{h}$ and purified according to the method described by Yamada \& Kondo (1973) and Kuraishi et al. (1985). Isoprenologues were identified by HPLC as described previously (Limtong et al., 2007a).

The sequences of the D1/D2 domain of the LSU rDNA of the two strains were identical. In the phylogenetic tree based on sequences of the D1/D2 domain of the LSU rDNA, the two strains were placed in the Yarrowia clade, supported by high bootstrap values (Fig. 1). Strains TM216 and PT $1-17^{\mathrm{T}}$ showed $13.2 \%$ divergence (64 nucleotide substitutions and two gaps out of $500 \mathrm{nt}$ ) from the type strain of Candida galli, the closest species in terms of pairwise sequence similarity. According to Kurtzman \& Robnett (1998), yeast strains showing nucleotide substitutions covering more than $1 \%$ of the D1/D2 domain of the LSU rDNA usually represent different species. The SSU rDNA sequences of the two strains were also identical (data not shown). Accordingly, the two strains represent a single, novel, phylogenetically distinct species.

Strains TM2-16 and PT $1-17^{\mathrm{T}}$ proliferated by multilateral budding (Fig. 2), gave negative Diazonium blue $\mathrm{B}$ and urease reactions and had Q-9 as the major ubiquinone. No ascospores were produced from individual strains or strains crossed on YM agar, 5\% malt extract agar, Fowell's acetate agar or Gorodkowa agar after 6 weeks at 15 or $28{ }^{\circ} \mathrm{C}$. The two strains also shared the same conventional taxonomic characteristics, as given in the 


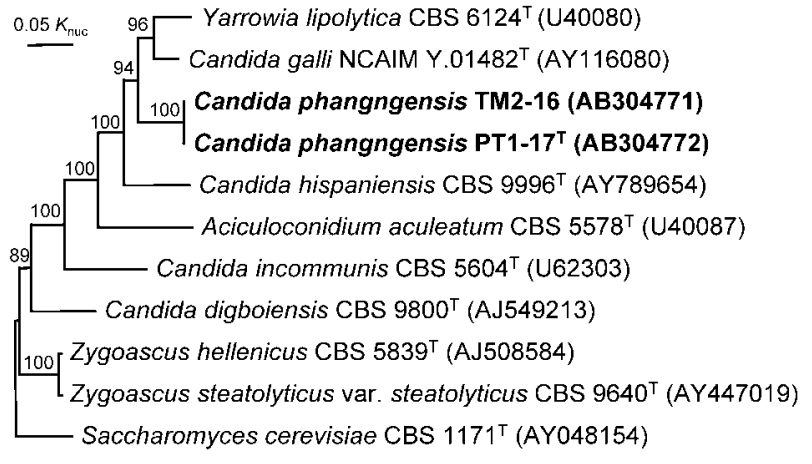

Fig. 1. Phylogenetic tree based on the D1/D2 domain of the LSU rDNA, showing the positions of strains PT1-17 ${ }^{\top}$ and TM2-16 (Candida phangngensis sp. nov.) with respect to closely related species. The phylogenetic tree was constructed from evolutionary distance data with Kimura's two-parameter correction (Kimura, 1980), using the neighbour-joining method. Numbers indicate percentages of bootstrap sampling, derived from 1000 samples.

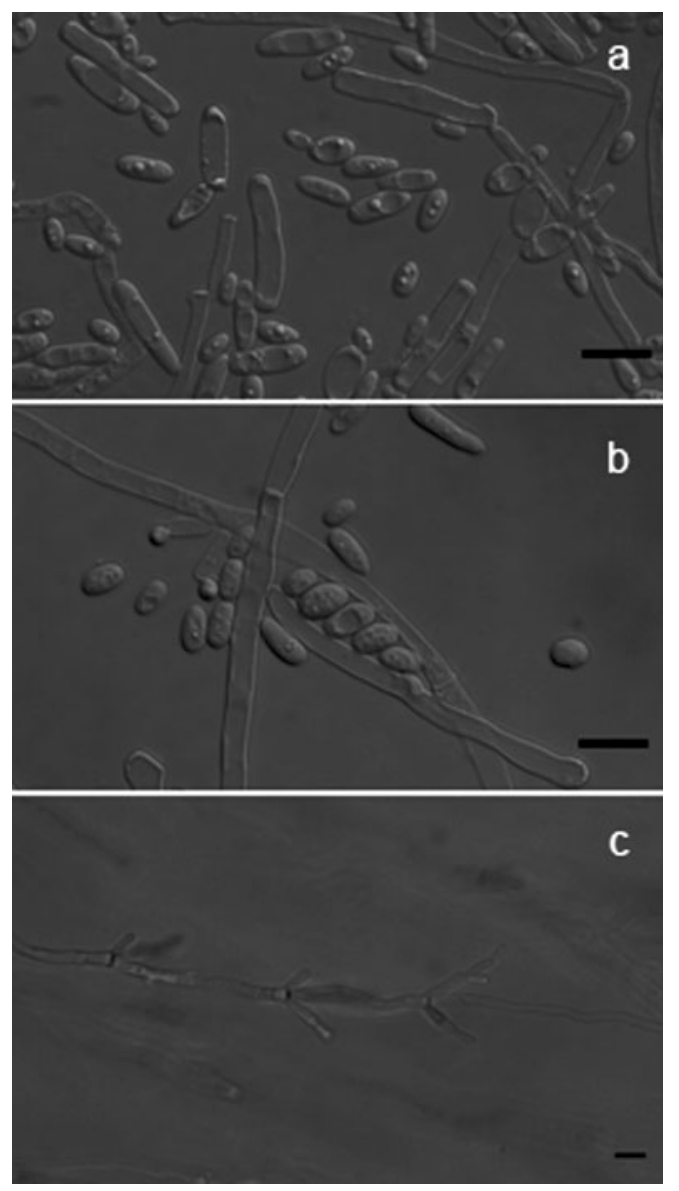

Fig. 2. Candida phangngensis sp. nov. PT1-1 $7^{\top}$. (a) Vegetative cells grown on YM agar after 3 days at $28{ }^{\circ} \mathrm{C}$; (b) septate hyphae; (c) pseudohyphae produced on cornmeal agar after 7 days at $28^{\circ} \mathrm{C}$. Bars, $10 \mu \mathrm{m}$. species description. We concluded, therefore, that the two strains represent a single, novel species of the genus Candida, for which the name Candida phangngensis sp. nov. is proposed. Although the formation of arthroconidia of this novel species is not a characteristic of the genus Candida, it has been observed in Candida lipolytica, the asexual state of Y. lipolytica, and in C. galli (Kurtzman, 1998; Péter et al., 2004).

In practice, Candida phangngensis sp. nov. can be distinguished from C. galli, its closest phylogenetic relative, on the basis of sequences of the D1/D2 domain of the LSU rDNA and a few phenotypic characteristics shown in Table 1. The novel species showed some differences in phenotypic characteristics from the other species of the Yarrowia clade (Table 1).

\section{Latin diagnosis of Candida phangngensis Limtong, Yongmanitchai, Kawasaki et Seki sp. nov.}

In agaro $\mathrm{YM}$ post dies 3 ad $28{ }^{\circ} \mathrm{C}$ cellulae globosae, ellipsoideae aut elongatae $(1.5-4 \times 2-7 \mu \mathrm{m})$, singulae, aut

Table 1. Characteristics that distinguish strains PT $1-17^{\top}$ and TM2-16 (Candida phangngensis sp. nov.) from related species

Species: 1, C. phangngensis (strains PT1-17 ${ }^{\mathrm{T}}$ and TM2-16); 2, C. galli (data from Péter et al., 2004); 3, Y. lipolytica (Kurtzman, 1998); 4, C. hispaniensis (Kurtzman, 2005); 5, A. aculeatum (Smith, 1998). +, Positive; -, negative; L, latent (delayed positive); w, weak; s, slow; v, variable; ND, no data.

\begin{tabular}{|c|c|c|c|c|c|}
\hline Characteristic & 1 & 2 & 3 & 4 & 5 \\
\hline \multicolumn{6}{|l|}{ Fermentation of: } \\
\hline Glucose & - & - & - & - &,$+ \mathrm{w}$ \\
\hline Sucrose & - & - & - & - & $\mathrm{V}$ \\
\hline Trehalose & - & - & - & - & $\mathrm{W}, \mathrm{s}$ \\
\hline \multicolumn{6}{|l|}{ Assimilation of: } \\
\hline D-Galactose & - & S, WS & $\mathrm{V}$ & - & - \\
\hline L-Sorbose & + & $\mathrm{v}$ & V & $\mathrm{w}$ & - \\
\hline $\mathrm{N}$-Acetyl-D-glucosamine & - & - & + & - & $\mathrm{ND}$ \\
\hline D-Ribose & - &,$- \mathrm{L}$ & $\mathrm{V}$ & - & - \\
\hline Sucrose & - & - & - & - & + \\
\hline Maltose & - & - & - & - & + \\
\hline Trehalose & - & $\mathrm{V}$ & - & + & + \\
\hline Cellobiose & - & - & $\mathrm{w},-$ & - & + \\
\hline Erythritol & + & + & + & - & - \\
\hline D-Mannitol & + &,$+ \mathrm{L}$ & + & + & + \\
\hline D-Gluconate & + & $+, \mathrm{S}, \mathrm{L}$ & $\mathrm{V}$ & - & - \\
\hline DL-Lactate & + & + & + & + & - \\
\hline Citrate & - & + & + & - & + \\
\hline Ethanol & + & + & + & $\mathrm{V}$ & + \\
\hline \multicolumn{6}{|l|}{ Growth at/with: } \\
\hline $35^{\circ} \mathrm{C}$ & + & - & ND & ND & ND \\
\hline $37^{\circ} \mathrm{C}$ & + & - & $\mathrm{V}$ & $\mathrm{V}$ & - \\
\hline $50 \%$ Glucose & $\mathrm{L}$ & - & ND & ND & - \\
\hline $10 \% \mathrm{NaCl}+5 \%$ glucose & $\mathrm{L}$ & + & - & ND & ND \\
\hline
\end{tabular}


binae, per geminationem multipolarem reproducentes. Cultura butyrosa, cremea, hirsuta, sublatum, margin fimbriata cum mycelio. In agaro farinae Zea mays post dies 7 ad $28{ }^{\circ} \mathrm{C}$ et agaro $\mathrm{YM}$ post dies 3 ad $25{ }^{\circ} \mathrm{C}$ pseudohyphae et hyphae formantur. Arthroconidia formantur. Ascosporae non formantur. In medio liquido $\mathrm{YM}$ post 3 ad $28{ }^{\circ} \mathrm{C}$, repens pellicula formatur. Fermentatio nulla. Glucosum, L-sorbosum, glycerolum, erythritolum, D-mannitolum, glucono- $\delta$ lactonum, acidum D-gluconicum, acidum DL-lacticum, acidum succinicum, ethanolum, ethylaminum, L-lysinum et cadaverinum assimilatur at non galactosum, N-acetyl-Dglucosaminum, D-ribosum, D-xylosum, L-arabinosum, D-arabinosum, L-rhamnosum, sucrosum, maltosum, trehalosum, cellobiosum, melibiosum, lactosum, raffinosum, melezitosum, inulinum, galactitolum, inositolum, acidum 2-ketogluconicum, acidum D-glucuronicum, acidum D-galacturonicum, acidum citricum, methanolum, kalium nitricum nec nitrium nitrosum. Crescit in temperatura $37{ }^{\circ} \mathrm{C}$ at non in $40{ }^{\circ} \mathrm{C}$. Non crescit sine vitaminis. Crescit $0.01 \%$ cycloheximido et $0.1 \%$ cycloheximido. Crescit (lente) in $50 \%$ glucosum, $60 \%$ glucosum et $10 \%$ natrii chloridum $/ 5 \%$ glucosum. Amylum non formatur. Ureum non hydrolysatur. Diazonium caeruleum B non respondens. Ubiquinonum majus: Q-9.

Typus stirps PT1-17 $7^{\mathrm{T}}\left(=\mathrm{BCC} 21231^{\mathrm{T}}=\mathrm{NBRC} 101967^{\mathrm{T}}\right.$ $=$ CBS $10407^{\mathrm{T}}$ ) isolatus ex aqua, Phang-Nga Provincia, Thailandia, conservatur in collectionibus culturarum quas BIOTEC Culture Collection, National Center for Genetic Engineering and Biotechnology, Thailand (Pathumthani, Thailand), NITE Biological Resource Center (Chiba, Japan) et Centraalbureau voor Schimmelcultures (Utrecht, The Netherlands) deposita est.

\section{Description of Candida phangngensis Limtong, Yongmanitchai, Kawasaki et Seki sp. nov.}

Candida phangngensis (phang.ngen'sis. N.L. fem. adj. phangngensis referring to Phang-Nga Province, Thailand, where the first two strains were isolated).

After growth on YM agar for 3 days at $28{ }^{\circ} \mathrm{C}$, cells are spheroidal, ellipsoid to elongate $(1.5-4 \times 2-7 \mu \mathrm{m})$ and occur singly or in pairs (Fig. 2). Budding is multilateral. The streak culture on YM agar after 3 days at $28{ }^{\circ} \mathrm{C}$ is butyrous, cream-coloured, hirsute and raised and the margin is fringed with filaments. In Dalmau plate culture on cornmeal agar at $28{ }^{\circ} \mathrm{C}$ after 7 days and YM agar at $25{ }^{\circ} \mathrm{C}$ after 3 days, pseudohyphae and septate hyphae are formed. Arthroconidia are produced. No ascospores are produced from individual strains on YM agar, $5 \%$ malt extract agar, Fowell's acetate agar or Gorodkowa agar after 5 weeks at $28{ }^{\circ} \mathrm{C}$ or when strains are mixed at $15{ }^{\circ} \mathrm{C}$ on the same sporulation media. In YM broth after 3 days at $28{ }^{\circ} \mathrm{C}$ and during growth on the surface of assimilation medium, creeping dry pellicles are present. After 3 weeks in YM broth, pellicles are thick and sink to the bottom of the tube and the medium become viscous. Fermentation is absent. D-Glucose, L-sorbose, glycerol, erythritol, mannitol,
D-glucono-1,5-lactone, D-gluconic acid, DL-lactic acid, succinic acid, ethanol, ammonium sulfate, ethylamine hydrochloride, L-lysine hydrochloride and cadaverine are assimilated, but D-galactose, $\mathrm{N}$-acetyl-D-glucosamine, Dribose, D-xylose, L- and D-arabinose, L-rhamnose, sucrose, maltose, trehalose, cellobiose, melibiose, lactose, raffinose, melezitose, inulin, galactitol, myo-inositol, 2-ketogluconic acid, D-glucuronic acid, D-galacturonic acid, citric acid, methanol, potassium nitrate and sodium nitrite are not assimilated. Growth at $25,30,35$ and $37{ }^{\circ} \mathrm{C}$ is positive, but there is no growth at $40{ }^{\circ} \mathrm{C}$. No growth in vitamin-free medium. Growth on media containing $0.01 \%$ and $0.1 \%$ cycloheximide is positive. Growth on media containing $50 \%$ glucose, $60 \%$ glucose and $10 \%(\mathrm{w} / \mathrm{v})$ sodium chloride/ $5 \%(\mathrm{w} / \mathrm{v})$ glucose is delayed positive. Starch-like compounds are not produced. Diazonium blue $B$ and urease reactions are negative. The major ubiquinone is Q-9.

The type strain, PT1- $17^{\mathrm{T}}\left(=\mathrm{BCC} 21231^{\mathrm{T}}=\mathrm{NBRC} 101967^{\mathrm{T}}\right.$ $=\mathrm{CBS} 10407^{\mathrm{T}}$ ), was isolated from water in a mangrove forest in Mu Ko Ra-Ko Prathong National Park, PhangNga Province, Thailand.

\section{Acknowledgements}

This work was supported in part by the Joint Program in the Field of Biotechnology under the National Research Council of Thailand, the National Science and Technology Development Agency of Thailand and the Japan Science and Technology Agency. Special thanks go to Associate Professor Poonpilai Suwanarit for her kind support and help in sample collection. Many thanks also go to Ms Chutima Sringiew, Ms Somjit Am-in and Ms Suthida Tuntigumton for laboratory assistance.

\section{References}

Aksornkoae, S. (1999). Mangrove: Ecology and Management. Bangkok: Kasetsart University Press (in Thai).

Altschul, S. F., Madden, T. L., Schäffer, A. A., Zhang, J., Zhang, Z., Miller, W. \& Lipman, D. J. (1997). Gapped BLAST and PSI-BLAST: a new generation of protein database search programs. Nucleic Acids Res 25, 3389-3402.

Fell, J. W., Statzell-Tallman, A. \& Kurtzman, C. P. (2004). Lachancea meyersii sp. nov., an ascosporogenous yeast from mangrove regions in Bahama Islands. Stud Mycol 50, 359-363.

Felsenstein, J. (1985). Confidence limits on phylogenies: an approach using the bootstrap. Evolution 39, 783-791.

Hagler, A. N. \& Ahearn, D. G. (1987). Ecology of aquatic yeasts. In The Yeasts, 2nd edn, vol. 2, Yeasts and the Environment, pp. 181-205. Edited by A. H. Rose \& J. S. Harrison. London: Academic Press.

Kimura, M. (1980). A simple method for estimating evolutionary rates of base substitutions through comparative studies of nucleotide sequences. J Mol Evol 16, 111-120.

Kuraishi, H., Katayama-Fujimura, Y., Sugiyama, J. \& Yokoyama, T. (1985). Ubiquinone systems in fungi. I. Distribution of ubiquinones in the major families of ascomycetes, basidiomycetes, and deuteromycetes, and their taxonomic implications. Trans Mycol Soc Jpn 26, 383-395.

Kurtzman, C. P. (1998). Yarrowia van der Walt \& von Arx. In The Yeasts, a Taxonomic Study, 4th edn, pp. 420-421. Edited by C. P. Kurtzman \& J. W. Fell. Amsterdam: Elsevier. 
Kurtzman, C. P. (2005). New species and a new combination in the Hyphopichia and Yarrowia yeast clades. Antonie van Leeuwenhoek 88, 121-130.

Kurtzman, C. P. \& Robnett, C. J. (1998). Identification and phylogeny of ascomycetous yeasts from analysis of nuclear large-subunit (26S) ribosomal DNA partial sequences. Antonie van Leeuwenhoek 73, 331-371.

Lachance, M. A. \& Starmer, W. T. (1998). Ecology and yeasts. In The Yeasts, a Taxonomic Study, 4th edn, pp. 21-30. Edited by C. P. Kurtzman \& J. W. Fell. Amsterdam: Elsevier.

Limtong, S., Yongmanitchai, W., Tun, M. M., Kawasaki, H. \& Seki, T. (2007a). Kazachstania siamensis sp. nov., an ascomycetous yeast species from forest soil in Thailand. Int J Syst Evol Microbiol 57, 419-422.

Limtong, S., Yongmanitchai, W., Kawasaki, H. \& Seki, T. (2007b). Candida thaimueangensis sp. nov., an anamorphic yeast species from estuarine water in a mangrove forest in Thailand. Int J Syst Evol Microbiol 57, 650-653.

Nakase, T. \& Suzuki, M. (1986). Bullera megalospora, a new species of yeast forming larger ballistospores isolated from dead leaves of Oryza sativa, Miscanthus sinensis and Sasa sp. in Japan. J Gen Appl Microbiol 32, 225-240.
Péter, G., Dlauchy, D., Vasdinyei, R., Tornai-Lehoczki, J. \& Deák, T. (2004). Candida galli sp. nov., a new yeast from poultry. Antonie van Leeuwenhoek 86, 105-110.

Saitou, N. \& Nei, M. (1987). The neighbor-joining method: a new method for reconstructing phylogenetic trees. Mol Biol Evol 4, 406-425.

Smith, M. Th. (1998). Aciculoconidium D. S. King \& S. C. Jong. In The Yeasts, a Taxonomic Study, 4th edn, pp. 439-440. Edited by C. P. Kurtzman \& J. W. Fell. Amsterdam: Elsevier.

Thompson, J. D., Gibson, T. J., Plewniak, F., Jeanmougin, F. \& Higgins, D. G. (1997). The CLUSTAL_X windows interface: flexible strategies for multiple sequence alignment aided by quality analysis tools. Nucleic Acids Res 25, 4876-4882.

Yamada, Y. \& Kondo, K. (1973). Coenzyme Q system in the classification of the yeast genera Rhodotorula and Cryptococcus and the yeast like genera Sporobolomyces and Rhodosporidium. J Gen Appl Microbiol 19, 59-77.

Yarrow, D. (1998). Methods for the isolation, maintenance and identification of yeasts. In The Yeasts, a Taxonomic Study, 4th edn, pp. 77-100. Edited by C. P. Kurtzman \& J. W. Fell. Amsterdam: Elsevier. 